\title{
Proglacial river stage, discharge, and temperature datasets from the Akuliarusiarsuup Kuua River northern tributary, Southwest Greenland, 2008-2011
}

\author{
A. K. Rennermalm ${ }^{1}$, L. C. Smith ${ }^{2}$, V. W. Chu ${ }^{2}$, R. R. Forster ${ }^{3}$, J. E. Box ${ }^{4}$, and B. Hagedorn ${ }^{5}$ \\ ${ }^{1}$ Department of Geography, Rutgers, The State University of New Jersey, 54 Joyce Kilmer Avenue, Piscataway, \\ NJ 08854-8045, USA \\ ${ }^{2}$ Department of Geography, University of California, Los Angeles, 1255 Bunche Hall, P.O. Box 951524 , \\ Los Angeles, CA 90095-1524, USA \\ ${ }^{3}$ Department of Geography, University of Utah, 260 S. Central Campus Dr., Salt Lake City, UT 84112, USA \\ ${ }^{4}$ Department of Geography, The Ohio State University, 1036 Derby Hall, 154 North Oval Mall, Columbus, \\ OH 43210-1361, USA \\ ${ }^{5}$ Environment and Natural Resources Institute, University of Alaska Anchorage, 3211 Providence Drive, \\ Anchorage, AK 99508, USA
}

Correspondence to: A. K. Rennermalm (asa.rennermalm@rutgers.edu)

Received: 8 July 2011 - Published in Earth Syst. Sci. Data Discuss.: 14 September 2011

Revised: 21 February 2012 - Accepted: 19 March 2012 - Published: 12 May 2012

\begin{abstract}
Pressing scientific questions concerning the Greenland ice sheet's climatic sensitivity, hydrology, and contributions to current and future sea level rise require hydrological datasets to resolve. While direct observations of ice sheet meltwater losses can be obtained in terrestrial rivers draining the ice sheet and from lake levels, few such datasets exist. We present a new hydrologic dataset from previously unmonitored sites in the vicinity of Kangerlussuaq, Southwest Greenland. This dataset contains measurements of river stage and discharge for three sites along the Akuliarusiarsuup Kuua (Watson) River's northern tributary, with 30 min temporal resolution between June 2008 and July 2011. Additional data of water temperature, air pressure, and lake stage are also provided. Flow velocity and depth measurements were collected at sites with incised bedrock or structurally reinforced channels to maximize data quality. However, like most proglacial rivers, high turbulence and bedload transport introduce considerable uncertainty to the derived discharge estimates. Eleven propagating error sources were quantified, and reveal that largest uncertainties are associated with flow depth observations. Mean discharge uncertainties (approximately the $68 \%$ confidence interval) are two to four times larger ( $\pm 19 \%$ to $\pm 43 \%$ ) than previously published estimates for Greenland rivers. Despite these uncertainties, this dataset offers a rare collection of direct measurements of ice sheet runoff to the global ocean and is freely available for scientific use at doi:10.1594/PANGAEA.762818.
\end{abstract}

\section{Introduction}

Mean annual air temperatures over the Greenland ice sheet have warmed $1.8^{\circ} \mathrm{C}$ between 1840 and 2007 (Box et al., 2009). This trend has continued since 2007 , with large surface air temperature anomalies along Greenland's coast in 2010 (Box et al., 2010), accompanied by a near-tripling of overall ice sheet mass balance losses since the 1960s (Rignot et al., 2008). Meltwater runoff losses are poorly constrained, but estimated to be as much as twice the ice flow discharge losses between 2000 and 2008 (van den Broeke et al., 2009). Continued and increased mass losses from the Greenland ice sheet may have far reaching consequences, contributing perhaps $17-54 \mathrm{~cm}$ to global sea level rise by 2100 (Table 3, line 3 in Pfeffer et al., 2008), while influencing regional meteorology (Dethloff et al., 2004) and ocean circulation in the North Atlantic (Driesschaert et al., 2007; Fichefet et al., 2003; Jungclaus et al., 2006). However, improved projections of 
future mass losses and their associated global and regional impacts require a better understanding of Greenland ice sheet hydrologic processes and runoff.

Where available, time series of proglacial river discharge can reveal insights about hydrologic connections between ice sheet surface melting and riverine meltwater losses (van de Wal and Russell, 1994), englacial water storage dynamics (Mathews, 1963), meltwater travel time (Elliston, 1973), seasonal changes in subglacial drainage systems (when combined with dye tracer analysis, Nienow et al., 1998), supraglacial lake drainages and the hydrologic drainage system (Bartholomew et al., 2011), catastrophic drainage events in the proglacial environment (Mernild and Hasholt, 2009; Mernild et al., 2008; Russell et al., 2011; Russell, 1989, 2009), and channel erosion and sediment transport processes (Russell et al., 1995; Russell, 2007). They are also valuable for estimating ice sheet meltwater losses, and for validation/calibration of ice sheet runoff models that estimate total meltwater losses for Greenland (Mernild et al., 2010, 2011) and elsewhere (Baker et al., 1982; Fountain and Tangborn, 1985; Hock and Noetzli, 1997; Klok et al., 2001; Verbunt et al., 2003). To date, only four peer-reviewed articles present analyses of such measurements in Greenland (Mernild and Hasholt, 2009; Russell et al., 1995; Russell, 2007; van de Wal and Russell, 1994), owing to logistical inaccessibility and difficulties in measuring river discharge in proglacial gravel-bed braided river systems (Ashmore and Sauks, 2006; Smith et al., 1996).

Here we present a new dataset (June 2008 to July 2011) of in situ hydrologic measurements collected at multiple, previously unmonitored proglacial sites in the upper Akuliarusiarsuup Kuua River drainage, Southwest Greenland. These include time series of river stage recorded every $30 \mathrm{~min}$, together with occasional in-channel measurements of flow width, depth, and velocity to establish empirical rating curves relating continuously recorded river stage to in situ discharge estimates. Other measurements include: lake stages, stream temperatures, and barometric air pressure. While three previous studies have monitored discharge and stages in the middle and lower parts of the Akuliarusiarsuup Kuua River drainage (Mernild and Hasholt, 2009; Russell et al., 1995; van de Wal and Russell, 1994), this is the first study to perform a comprehensive error assessment. Although discharge measurements were made at sites with near-ideal geomorphology (incised bedrock and structurally reinforced channels) strongly turbulent flows and high sediment bedloads degrade precision of the derived discharge estimates. To assess data precision, eleven error sources were considered, including uncertainties associated with changing streambed elevation, measurement errors, and rating curve fitting. Streambed elevation trends and variability were studied in depth with statistical techniques. All errors were factored in to establish rating curves for upper and lower discharge ranges that represented approximately the $68 \%$ confidence interval of discharge estimates.

\section{Site description}

Three continuous river monitoring sites (Sites AK2, AK3, and AK4, Fig. 1, Table 1), one lake, and one additional river site with shorter period observations (Sites AK1, and AK5, Fig. 1, Table 1) were selected along the Akuliarusiarsuup Kuua River's northern tributary. The Akuliarusiarsuup Kuua River is the northern branch of the Watson River that discharges into Kangerlussuaq Fjord near the town of Kangerlussuaq. All sites are located in the ice sheet proglacial zone, within $2 \mathrm{~km}$ of the ice edge and $27-30 \mathrm{~km}$ northeast of Kangerlussuaq. Watersheds of Sites AK3 and AK4 are 7.8 and $64.2 \mathrm{~km}^{2}$, respectively, and are both sub-watersheds nested within Site AK2's larger 101.4 km² watershed (Fig. 1 lower inset). Watersheds were delineated using ice sheet surface elevation data from the Advanced Spaceborne Thermal Emission and Reflection Radiometer (ASTER) global digital elevation map of surface topography (METI and NASA, 2009) using ESRI's ArcGIS hydrology tool. While delineations based only on surface topography have precedence (Mernild et al., 2010), accuracy of watershed delineations improves with inclusion of basal topography owing to the effect of hydrostatic pressure on the hydraulic potentiometric surface (Cuffey and Paterson, 2010; Lewis and Smith, 2009). Pending availability of such data these delineations based on surface topography only can be considered a first approximation. Meltwater runoff from the Greenland ice sheet is transported to these sites (AK2, AK3, and AK4) via different proglacial pathways, with varying degrees of upstream impoundment in lakes (Fig. 1). Prior to reaching Site AK4, ice sheet meltwater is routed through one lake, whereas flows to Site AK3 first pass through 3-4 lakes. Site AK2 integrates all water flow discharging from Lake A (Fig. 1), which includes flows from both Sites AK3 and AK4, plus a third inlet connecting Lake A and B at the southern side of the drainage basin. Upstream of this third inlet are two lakes (B and C), of which Lake $\mathrm{C}$ is usually ice dammed, causing meltwater to be routed to Lake B via an intermittent stream (Russell et al., 2011). Catastrophic drainage of the ice dammed Lake C occurred in 1984, 1987, 2007 and 2008 (Mernild and Hasholt, 2009; Mernild et al., 2008; Russell et al., 2011; Russell, 1989, 2007, 2009). When the ice dam bursts, Lake C no longer drains via the intermittent stream but instead discharges to Lake B along the ice margin (Russell et al., 2011).

\section{Methods}

River stage (e.g. water level), temperature, and discharge measurements were collected at Sites AK2, AK3, and AK4 (Table 1) between June 2008 and July 2011. Uncorrected stage, $L_{\mathrm{w}-\mathrm{uc}}$, (Fig. 2) was determined as the difference between measured water pressure from submerged Solinst Levelogger pressure transducers (nominal precision $0.3 \mathrm{~cm}$ ), and barometric air pressure was recorded simultaneously with Solinst Barologger pressure transducers (nominal precision 


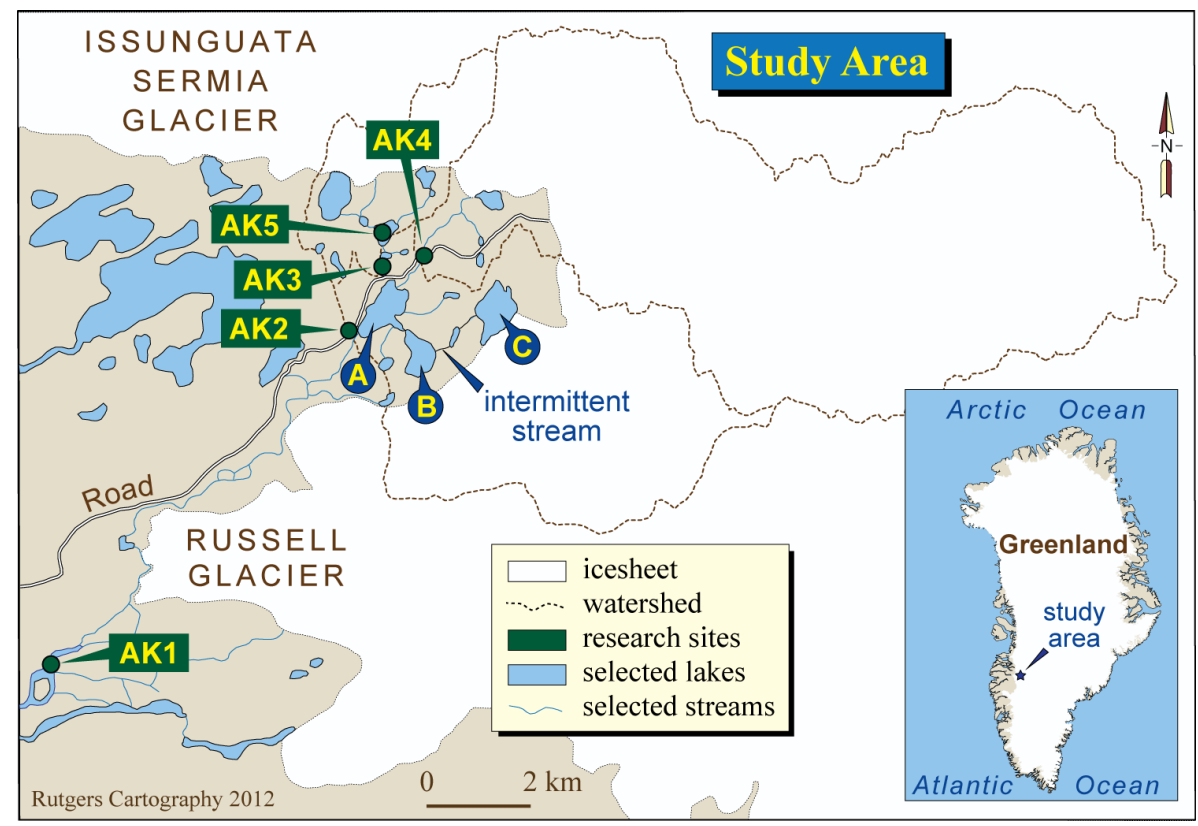

Figure 1. Map of site locations in the proglacial environment and watershed boundaries upstream Sites AK2, AK3, and AK4, inset of Greenland map with study area (lower right corner).

Table 1. Study sites and dataset variables. Dataset variables are: surface pressure $\left(p_{\mathrm{s}}\right)$, total pressure measured with solinst levelogger in stream, $\left(p_{\mathrm{t}}\right)$, water pressure $\left(p_{\mathrm{w}}\right)$, uncorrected stage $\left(L_{\mathrm{w}-\mathrm{uc}}\right)$, stage $\left(L_{\mathrm{w}}\right)$, water temperature $(T)$, discharge $(Q)$, upper range of discharge $\left(Q_{\mathrm{u}}\right)$, and lower range of discharge $\left(Q_{1}\right)$. Dataset also contain flags when dataset were augmented during data gaps.

\begin{tabular}{ccccclc}
\hline Site & Full site name & Latitude & Longitude & Elevation $(\mathrm{m})$ & Measured parameters & DOI \\
\hline AK1 & AK-001-001 & 67.078031 & -50.276525 & 150 & $p_{\mathrm{s}}$ & doi:10.1594/PANGAEA.762816 \\
AK2 & AK-002-001 & 67.132282 & -50.138113 & 340 & $p_{\mathrm{t}}, p_{\mathrm{w}}, L_{\mathrm{w}-\mathrm{uc}}, L_{\mathrm{w}}, T, Q, Q_{\mathrm{u}}, Q_{1}$ & doi:10.1594/PANGAEA.762817 \\
AK2 & AK-002-002 & 67.131681 & -50.137597 & 340 & $p_{\mathrm{s}}$ & doi:10.1594/PANGAEA.762890 \\
AK3 & AK-003-001 & 67.143023 & -50.122732 & 340 & $p_{\mathrm{t}}, p_{\mathrm{w}}, L_{\mathrm{w}-\mathrm{uc}}, L_{\mathrm{w}}, T, Q, Q_{\mathrm{u}}, Q_{1}$ & doi:10.1594/PANGAEA.762895 \\
AK4 & AK-004-001 & 67.146558 & -50.106616 & 340 & $p_{\mathrm{t}}, p_{\mathrm{w}}, L_{\mathrm{w}-\mathrm{uc}}, L_{\mathrm{w}}, T, Q, Q_{\mathrm{u}}, Q_{1}$ & doi:10.1594/PANGAEA.762897 \\
AK5 & AK-005-001 & 67.149556 & -50.125860 & 340 & $p_{\mathrm{t}}, p_{\mathrm{w}}, L_{\mathrm{w}}$ & doi:10.1594/PANGAEA.762898 \\
\hline
\end{tabular}

$0.1 \mathrm{~cm}$ ) on land every $30 \mathrm{~min}$. Leveloggers were enclosed in perforated steel boxes at the end of $1.5-3 \mathrm{~m}$ steel rods attached to bedrock or rocks, thus allowing direct emplacement in the stream without resting on the channel bed (Fig. 2, foreground). These boxes were maintained at a fixed depth relative to a datum plane and located within $1-30 \mathrm{~m}$ of the cross section used for in situ discharge measurements. Barologgers measuring air pressure were installed $150 \mathrm{~m}$ from Site AK2 (Table 1) and assumed representative for all three gauging sites given the close proximity of these sites (less than $2 \mathrm{~km}$ ) and the limited elevation differences between the sites. Data were retrieved from loggers in early June and late $\mathrm{Au}-$ gust of each year. From August to June, Leveloggers were placed in rubber balloons filled with antifreeze solution to protect sensors from extreme pressures during freezing conditions (Solinst Inc., 2011). Despite this precaution, some wintertime recordings displayed extreme pressure fluctua- tions probably due to freezing, and were discarded from the dataset. Brief data gaps occurring during logger retrieval and data downloading were filled using a second, temporary sensor placed in the river. Estimated true stage at Levelogger installation sites, $L_{\mathrm{w}}$, was calculated by adding $L_{\mathrm{w}-\mathrm{uc}}$ to the distance from logger steelbox to the stream bed, $d_{\mathrm{box}}$ (Table 3, Fig. 2), $d_{\text {box }}$ was $65 \mathrm{~cm}$ at Site AK2, and mean $d_{\text {box }}$ and standard deviation was $15.4 \pm 2.7 \mathrm{~cm}$ and $15.4 \pm 2.8 \mathrm{~cm}$ for Sites AK3 and AK4. Additionally, $L_{\mathrm{w}}$ time series were (1) corrected for minor discontinuities in $L_{\mathrm{w} \text {-uc }}$ due to slight differences in Levelogger placement in steel box following Levelogger retrieval for data downloading by matching time series before and after these discontinuities; (2) forced to zero during prolonged periods with subzero temperatures unless constant subzero temperatures persisted for days, which indicate phase changes. At Site AK4, occasional sensor exposure to air revealed an offset from zero $L_{\mathrm{w} \text {-uc }}$ values. These 


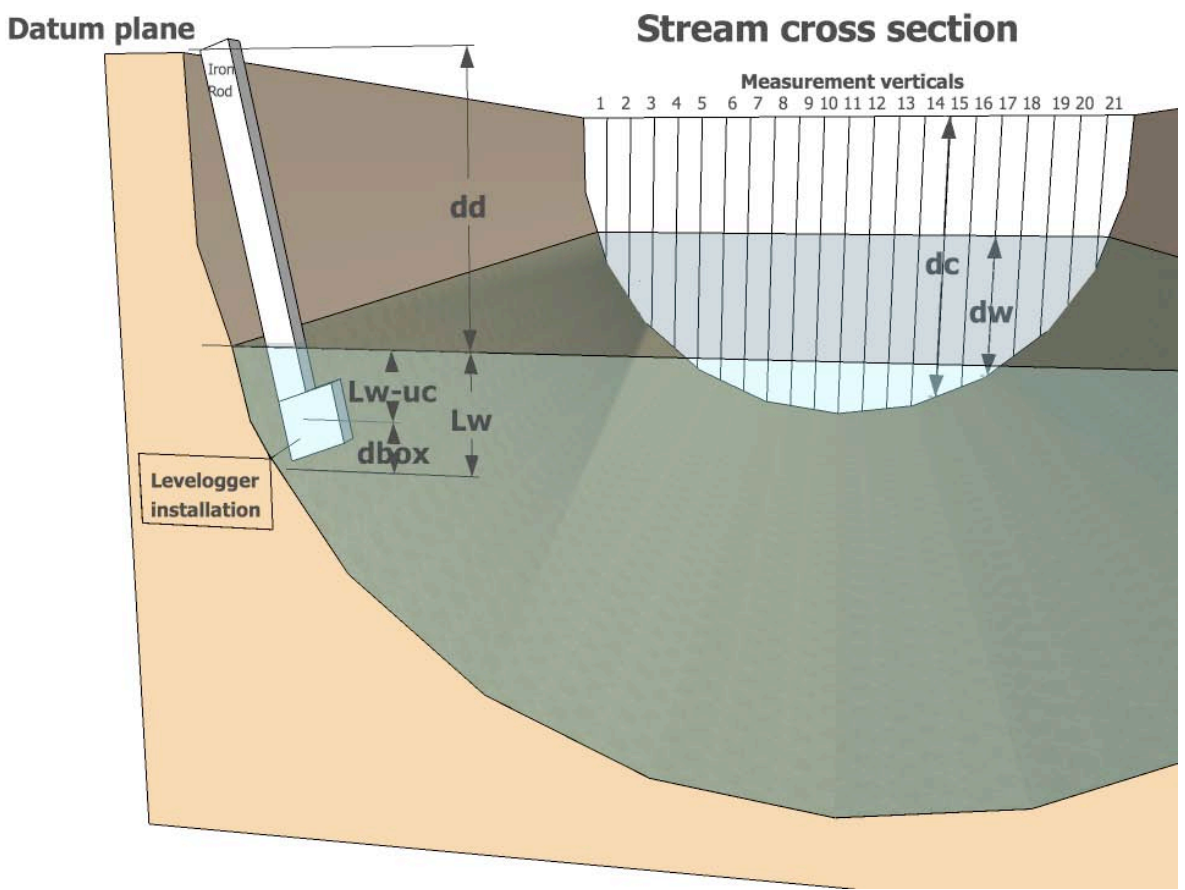

Figure 2. Schematic figure showing installation setup at Site AK2. A Solinst Levelogger is installed in a perforated steel box attached to an iron rod bolted to bedrock (foreground) where the top of the iron rod defines the datum plane. The vertical distance from datum to Levelogger is denoted $d_{\mathrm{d}}$, stage (estimated true distance from stream bed to water surface) is denoted $L_{\mathrm{w}}$, distance from Levelogger to streambed is denoted $d_{\mathrm{box}}$, and uncorrected stage recorded by Leveloggers corrected for barometric pressure fluctuations, $L_{\mathrm{w}-\mathrm{uc}}$, is distance from Levelogger to time varying water surface. Upstream of Levelogger installation $(30 \mathrm{~m})$ is the stream cross section where in situ discharge measurements are conducted at 21 measurement verticals (background). At each vertical, measurements are made of water depth $\left(d_{\mathrm{w}}\right)$ and stream velocity at $0.6 d_{\mathrm{w}}(2010)$, or $0.2 d_{\mathrm{w}}$ and $0.8 d_{\mathrm{w}}(2011)$. Distance from streambed to datum plane is also estimated at each vertical $\left(d_{\mathrm{c}}\right)$. Lengths of $d_{\mathrm{c}}$ and $d_{\mathrm{w}}$ are illustrated for interval 15 and 17 respectively, but are measured for all verticals 1 to 21 . Installation setups at Sites $\mathrm{AK} 3$ and AK4 are the same, except that datum planes are defined by a bridge, 31 or 16 verticals were used, and the Levelogger installation are in closer proximity $(1 \mathrm{~m})$ to measurement verticals.

offsets were removed from $L_{\mathrm{w}}$ values during and before sensor exposure. Offsets were quantified as median deviations, which were $8.1 \mathrm{~cm}, 5.4 \mathrm{~cm}$, and $-0.059 \mathrm{~cm}$, for periods 18 to 22 October 2008, 12 to 23 September 2009, 9-13 September 2010.

Discharge, $Q$, was determined using the standard midsection method (WMO, 2010b), which involved collection of average velocity and water depth, $d_{\mathrm{w}}$, at 21,33 , and 16 measurement verticals in stream cross sections at Sites AK2, AK3 and AK4. Observations were made in channels with near-ideal geomorphologic properties compared to standards stated by the World Meteorological Organization (WMO, 2010b) (Table 2). Stream cross sections consisted of one incised bedrock channel (Site AK2) and two structurally reinforced bridge crossings (Site AK3, and AK4), which are likely to remain stable even during high flow (Table 2). Stream banks were sufficiently high to prevent overtopping, and free of vegetation (Table 2). Channels were relatively straight for near-ideal distance both upstream and downstream, and confined all flow through Sites AK2 and AK3 and the majority of flow through Site AK4 (Table 2). Each cross section was marked at $1.0 \mathrm{~m}, 0.25 \mathrm{~m}$, and $0.5 \mathrm{~m}$ intervals dividing the cross section into a 21, 31, and 16 measurement verticals at Sites AK2, AK3, and AK4, respectively, using the bridges at Sites AK3 and AK4, and a suspended rope at Site AK2 (Fig. 2, background). Horizontal spacing between verticals was chosen to ensure adequate numbers of measurement points during low flow conditions. At each vertical, measurements of $d_{\mathrm{w}}$ and velocity were collected using measurement rod/tape, and Price-type AA current meter. At Site AK2, velocity measurements were made at $0.6 d_{\mathrm{w}}$ in 2010, and at $0.2 d_{\mathrm{w}}$ and $0.8 d_{\mathrm{w}}$ in 2011, which typically provides average velocity along a vertical (e.g. WMO, 2010b). At Sites AK3 and AK4, velocity was measured approximately $0.1-0.3 \mathrm{~m}$ below the water surface. Here, stream flows were highly turbulent, shallow, and well mixed with a near-vertical velocity profile above the bed. Duplicate measurements conducted confirmed reproducibility of these near-surface velocity measurements at Sites AK3 and AK4. Thus, velocities determined at Sites AK3 and AK4 satisfied the measurement goals of determining average stream velocity for each vertical. 
Table 2. Criteria for selection of ideal discharge and water stage monitoring sites defined by World Meteorological Organization (WMO, 2010b), and characteristics of observation sites in this study.

\begin{tabular}{|c|c|c|c|}
\hline $\begin{array}{l}\text { WMO characteristics of ideal } \\
\text { monitoring sites }\end{array}$ & Site AK2 & Site AK3 & Site AK4 \\
\hline $\begin{array}{l}\text { Sites with natural channels } \\
\text { should be stable to ensure va- } \\
\text { lidity of stage-discharge rela- } \\
\text { tionship }\end{array}$ & $\begin{array}{l}\text { Near-ideal site at bedrock in- } \\
\text { cised channel and large boul- } \\
\text { ders }\end{array}$ & $\begin{array}{l}\text { Near-ideal site at bridge } \\
\text { crossing reinforced with } \\
\text { large boulders }\end{array}$ & $\begin{array}{l}\text { Near-ideal site at bridge } \\
\text { crossing reinforced with } \\
\text { large boulders }\end{array}$ \\
\hline $\begin{array}{l}\text { Stream channel should be } \\
\text { straight } 10 \text { times the stream } \\
\text { width both upstream and } \\
\text { downstream the monitoring } \\
\text { site }\end{array}$ & $\begin{array}{l}\text { Ideal downstream conditions, } \\
\text { upstream channel is straight } \\
\text { approximately } 5 \text { times the } \\
\text { stream width }\end{array}$ & $\begin{array}{l}\text { Ideal upstream conditions, } \\
\text { downstream channel is } \\
\text { straight but widens into a } \\
\text { lake }\end{array}$ & Ideal conditions \\
\hline $\begin{array}{l}\text { Flow should be confined to } \\
\text { one channel with no flow by- } \\
\text { passing the site as subsurface } \\
\text { flow }\end{array}$ & Ideal conditions & Ideal conditions & $\begin{array}{l}\text { Some flow bypass the rein- } \\
\text { forced channel }\end{array}$ \\
\hline $\begin{array}{l}\text { Stream bed should be free of } \\
\text { vegetation and have no scour } \\
\text { and fill }\end{array}$ & Ideal conditions & Ideal conditions & Ideal conditions \\
\hline $\begin{array}{l}\text { Banks should be permanent, } \\
\text { high enough for floods, and } \\
\text { vegetation free }\end{array}$ & Ideal conditions & $\begin{array}{l}\text { Near-ideal conditions. While } \\
\text { the bridge set an upper limit } \\
\text { for high flow observations, } \\
\text { observed stage has never } \\
\text { reach this limited }\end{array}$ & $\begin{array}{l}\text { High flow may reach the bot- } \\
\text { tom of the bridge, but this oc- } \\
\text { curs rarely }\end{array}$ \\
\hline $\begin{array}{l}\text { Discharge gauging site } \\
\text { should be in proximity of } \\
\text { stage monitoring site }\end{array}$ & Ideal conditions & Ideal conditions & Ideal conditions \\
\hline $\begin{array}{l}\text { Gauging site must not be af- } \\
\text { fected by downstream con- } \\
\text { fluence of other streams }\end{array}$ & Ideal conditions & $\begin{array}{l}\text { Influence from downstream } \\
\text { lake has been detected during } \\
\text { extreme high lake stage }\end{array}$ & Ideal conditions \\
\hline
\end{tabular}

To assess changes and variability in streambed elevation over time relative to a fixed point, cross sectional stream depths $\left(d_{\mathrm{c}}\right)$ were determined relative to a datum plane defined as the bottom edge of a steel beam supporting a bridge crossing the river (Sites AK3, and AK4) or the top of the iron rod installation (Site AK2, Fig. 2). At Sites AK3 and $\mathrm{AK} 4, d_{\mathrm{c}}$ was measured from the bridges, simultaneous with $d_{\mathrm{w}}$, and velocity. At Site AK2, physical separation of datum plane and channel cross section made simultaneous measurements impossible (Fig. 2). Instead, $d_{\mathrm{c}}$ was determined with a linear regression model constructed by relating occasional datum plane measurements to Solinst water depth recordings: $d_{\mathrm{c}}=d_{\mathrm{w}}+d_{\mathrm{d}}-c_{1} L_{\mathrm{w}}-c_{2}$; where $d_{\mathrm{c}}$ is the cross sectional stream depth from datum plane at a vertical, $d_{\mathrm{w}}$ is the cross section water depth, $d_{\mathrm{d}}$ is vertical distance between datum and Solinst Levelogger enclosure, $L_{\mathrm{w}}$ is estimated vertical distance between water surface and stream bed at Solinst Levelogger site. The coefficients $c_{1}$ and $c_{2}$ were determined through linear regression $\left(c_{1}=1.0, c_{2}=0.2 \mathrm{~m}\right)$. Modeled and measured cross sectional stream depth correlated strongly $(r=1.0)$; hence, modeled $d_{\mathrm{c}}$ were used at Site AK2. The most accurate $d_{\mathrm{c}}$ and $d_{\mathrm{w}}$ measurements were made in 2011 when sturdy rods and heavy sounding weights limited the influence of turbulence on depth measurements.

Time series of $Q$ were derived by the typically used method of fitting first-degree power functions to occasional in situ measurements of $Q$ and true stage $\left(L_{\mathrm{w}}-d_{0}\right)$ at corresponding times (e.g. WMO, 2010a), where $d_{0}$ is the water depth at zero discharge determined as minimum $L_{\mathrm{w}}$. Power function best-fit parameters were determined with a nonlinear least squares method. To fit the rating curve, 11, 25, and 29 in situ $Q$ measurements were used for Sites AK2, AK3 and AK4, respectively. At Site AK2, an eleventh point was added to represent peak conditions during the 31 August 2008 jokulhlaup triggered by drainage of the ice dammed lake (Lake $C$ ) by matching the recorded maximum $L_{\mathrm{w}}(384 \mathrm{~cm})$ with an independent estimate of peak discharge $\left(416 \mathrm{~m}^{3} \mathrm{~s}^{-1}\right)$ from the ice dammed lake (Russell et al., 2011). 
Indeed, calculated jokulhluap volume $\left(11.5 \times 10^{6} \mathrm{~m}^{3}\right)$ was similar to a previous volume estimate based on detailed field surveying $\left(12.9 \times 10^{6} \mathrm{~m}^{3}\right)$ (Russell et al., 2011).

In addition to pressure, Solinst Levelogger instrument records ambient water temperatures with a nominal precision of $+0.05^{\circ} \mathrm{C}$. These temperature time series are supplied for Sites AK2, AK3, and AK4. The majority of winter stream temperature recordings at Site AK2 were discarded from the dataset because they were impacted by river ice in some years, and water in other years. Winter stream temperatures at Site AK3 and AK4 were preserved in the dataset despite shifting influence by water, ice, and air conditions because they provided insights into occasional wintertime water phase changes. Lake stage and water temperature observations were collected at Site AK5 (Table 1) for a single year between 2 June 2007 and August 19, 2008. Barometric pressure was collected at Site AK1 between 2 June 2007 and 21 August 2009 (Table 1). These observations are also included in the presented dataset.

\subsection{Discharge uncertainty and stream bed stability assessment}

Although observations were made at sites with near-ideal channel properties (Table 2), precise discharge estimates are typically difficult in high-bedload proglacial rivers owing to high flow velocities, turbulence, and bedload transport rates (Ashmore and Sauks, 2006; Smith et al., 1996). Therefore, discharge uncertainty ranges were quantified. An error propagation methodology similar to Sauer and Meyer (1992) was applied and extended to include errors associated with rating curve fitting and Solinst Levelogger water depth observations:

$E_{\mathrm{q}}=\sqrt{E_{\mathrm{d}}^{2}+E_{\mathrm{t}}^{2}+E_{\mathrm{i}}^{2}+E_{\mathrm{s}}^{2}+E_{\mathrm{h}}^{2}+E_{\mathrm{v}}^{2}+E_{\mathrm{sb}}^{2}+E_{\mathrm{sd}}^{2}+E_{\mathrm{sv}}^{2}+E_{L_{\mathrm{w}}}^{2}+E_{\mathrm{fit}}^{2}}$

where $E_{\mathrm{q}}$ is discharge estimate error (\%), determined by the percent error from: $E_{\mathrm{d}}=$ depth observation error, $E_{\mathrm{t}}=$ velocity pulsation error, $E_{\mathrm{i}}=$ current meter instrument error, $E_{\mathrm{s}}=$ velocity distribution error in the vertical, $E_{\mathrm{h}}=$ flow angle error, $E_{\mathrm{v}}=$ horizontal distribution error of velocity and depth, $E_{\mathrm{sb}}=$ systematic error in width measurements, $E_{\mathrm{sd}}=$ systematic error in depth measurements, $E_{\mathrm{sv}}=$ systematic error in velocity measurements, $E_{L_{\mathrm{w}}}=L_{\mathrm{W}}$ uncertainty due to Solinst instrument precision and retrieval, $E_{\text {fit }}=$ rating curve fitting error.

$E_{\mathrm{d}}$ was determined as mean measurement vertical standard error of $\left(d_{\mathrm{c}}-d_{\mathrm{c}}^{*}\right) / 0.01 d_{\mathrm{w}}$, where $d_{\mathrm{c}}$ is vertical datum depth, $d_{\mathrm{c}}^{*}$ is mean vertical datum depth in 2011 deployment, and $d_{\mathrm{w}}$ is vertical water depth. $E_{\mathrm{t}}$ was determined as the mean standard error using seven pairs of area-weighted velocity measurements made occasionally at Site AK4. $E_{\mathrm{h}}$ was set to $1 \%$, which allows 5 degrees uncertainty of flow angles on to the measurement (WMO, 2010b). $E_{\mathrm{i}}, E_{\mathrm{s}}, E_{\mathrm{v}}, E_{\mathrm{sb}}, E_{\mathrm{sd}}$, $E_{\mathrm{Sv}}$ were identified using relationships and guidelines provided by Sauer and Meyer (Sauer and Meyer, 1992). $E_{L_{\mathrm{w}}}$ was established as the percent error resulting from fitting the rating curve with maximum standard error of matching time series before and after data downloading, and Solinst Levelogger precision added and subtracted from $L_{\mathrm{w}}$. $E_{\mathrm{fit}}$ was determined as the root mean square error from fitting discharge measurement to a power-law rating curve expressed in percent of discharge. As most error terms were calculated as standard errors, $E_{\mathrm{q}}$ can be interpreted as approximately the $68 \%$ confidence interval of discharge observations.

Uncertainty ranges for continuous $Q$ time series derived from $L_{\mathrm{w}}$ were quantified with rating curves specifying upper and lower discharge ranges, $Q_{\mathrm{u}}$ and $Q_{1}$, respectively. Rating curve parameters were determined with non-linear leastsquare method by fitting power law functions to in situ discharge with added/subtracted $E_{\mathrm{q}}$. Furthermore, fitting was constrained to ensure proportionality between confidence interval and discharge magnitude. $Q_{1}$ and $Q_{\mathrm{u}}$ envelope approximately the $68 \%$ confidence interval of discharge (because maximum error is used for $E_{L_{\mathrm{w}}}$ it may be higher than $68 \%$ ), meaning that the true discharge value is within the upper and lower $Q$ boundaries at least $68 \%$ of the time.

Derivation of continuous $Q$ time series from rating curves implicitly assumes stable $d_{\mathrm{c}}$. This was examined by calculating the slope of depth changes at each vertical between June 2008 and July 2011 using linear regression analysis. Statistical significance of these slopes was established with two-sided t-tests testing the null hypothesis that these slopes were statistically similar to zero $(\alpha=0.1)$. Thus, rejecting the null hypothesis indicates $d_{\mathrm{c}}$ changes between June 2008 and July 2011. Two sources of flow depth error propagate uncertainty to derived discharge estimates: (1) temporal changes in bed elevation, which may increase or decrease the distance between the suspended pressure transducer and the channel floor $\left(d_{\text {box }}\right)$; and (2) human measurement error associated with $d_{\mathrm{w}}$ observatons in turbulent flow using steel rods and tapes.

To further explore $d_{\mathrm{c}}$ variability, a one-way ANOVA analysis was employed to test the null hypothesis that deployment mean $d_{\mathrm{c}}$ was statistically similar during all field deployments. Separate ANOVA tests were applied for each measurement vertical. Accepting the null hypothesis suggests that $d_{\mathrm{c}}$ is statistically similar over time, and it can be inferred that observed temporal variability is likely due to measurement errors. This interpretation hinges on the assumptions that $d_{\mathrm{c}}$ variability within each field deployment represents measurement uncertainty. This is a reasonable assumption given that field deployments were short ( $<7$ days) and no major flooding occurred that could change streambed morphology. In contrast, different $d_{\mathrm{c}}$ means, and significant slopes are suggestive of changing bed elevation, but could also be a result of measurement bias from different methods, and stream conditions over time. Finally, ANOVA tests include calculation of between-, $\sigma_{\mathrm{B}}$, and within-group variability, $\sigma_{\mathrm{W}}$, which were used to examine relative magnitudes $d_{\mathrm{c}}$ error dispersions during and between deployments. 


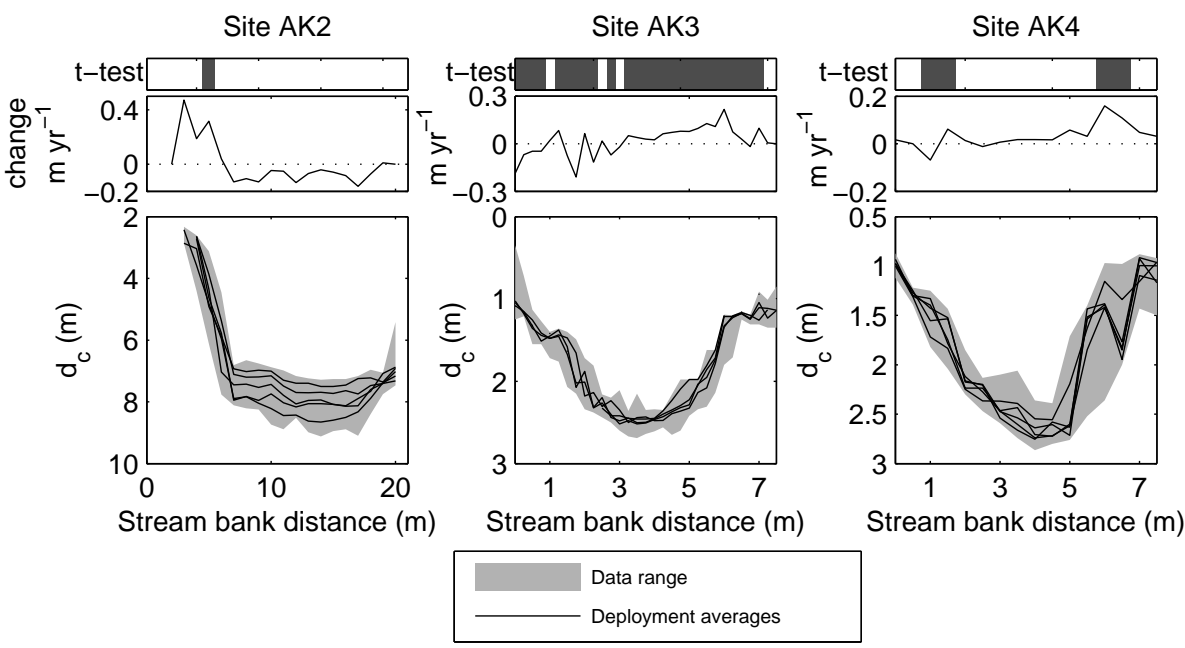

Figure 3. Streambed elevation changes, and depth measurement variability. Top panels show outcome of t-test (gray shaded region show rejected null hypothesis indicating significant change) suggesting changes in the majority of Site AK3 channel, but limited changes at Sites AK2 and AK4. Middle panels show streambed changes over time at each vertical in cross sections determined with linear regression models. Bottom panels show $d_{\mathrm{c}}$ measurement range (gray), and mean $d_{\mathrm{c}}$ in field deployments (black). Large $d_{\mathrm{c}}$ range is observed at all sites, but most variability in mean $d_{\mathrm{c}}$ is at Site AK2.

\subsection{Comparison of discharge magnitudes between sites in the AK-river system}

Discharge from the three monitored sites, and two additional sites reported in literature (Russels and Watson Sites, $9 \mathrm{~km}$ and $32 \mathrm{~km}$ downstream of Site AK2) were analyzed for consistency with a back-of-the-envelope method. The watersheds of these five sites are all within the $\mathrm{AK}$ and Watson river systems and are subjected to similar synoptic weather conditions. However, differences in ice sheet watershed size and elevation should result in varying absolute and specific discharge ( $=$ discharge/watershed area) between sites. Absolute and specific discharge were compared between the sites with the following expected outcomes: (1) absolute discharge should be proportional to area, because smaller watersheds are sub watersheds in the larger watersheds (the only exception is Site AK3, which is not a sub watershed of Site AK4); (2) specific discharge should be inversely proportional to area because larger watersheds extend further onto higher ice sheet elevations where runoff production is smaller (e.g. Mernild et al., 2010, 2011).

\section{Results}

Even using near-ideal channel cross sections, surveyed $d_{\mathrm{c}}$ show considerable variability. Large data ranges, and different deployment mean $d_{\mathrm{c}}$ are observed at all sites particularly at Site AK2 (Fig. 3). While largest absolute variation is at Site AK2 (shown by $\bar{\sigma}\left(d_{\mathrm{c}}-\bar{d}_{\mathrm{c}}^{*}\right)$, Table 3 ), depth measurement variability influences discharge most strongly at Site AK3. At Site AK3, shallow mean water depths results in large relative variation (shown by $d_{\mathrm{w}}$ and $\bar{C}_{\mathrm{v}}\left(d_{\mathrm{c}}-\bar{d}_{\mathrm{c}}^{*}, d_{\mathrm{w}}\right)$, Table 3 ). Site
AK3 is also the only site with a large fraction of measurement verticals with significant $d_{\mathrm{c}}$ trends (Table 3, Fig. 3). Significant trends for sites are both positive and negative, with mean change between $8 \mathrm{~cm} \mathrm{yr}^{-1}$ and $32 \mathrm{~cm} \mathrm{yr}^{-1}$ (Table 3). These trends may reflect actual channel morphology change as well as $d_{\mathrm{c}}$ observation uncertainty due to differences in methodology and flow conditions between deployments. Regardless of trend magnitude, a majority of measurement verticals underwent changes in mean $d_{c}$ between 2008 and 2011, verified by rejecting the null hypothesis of stable mean with one-way ANOVA tests (Table 3). ANOVA tests also confirm that $d_{\mathrm{c}}$ variability between deployments were greater than $d_{\mathrm{c}}$ measurements made within deployments $\left(\sigma_{\mathrm{W}}^{2} / \sigma_{\mathrm{B}}^{2}<1\right.$, Table 3$)$, and that greatest relative variability in mean deployment $d_{\mathrm{c}}$ were at Site AK2 (lowest $\sigma_{\mathrm{W}}^{2} / \sigma_{\mathrm{B}}^{2}<1$, Table 3).

Empirical stage-discharge rating curves satisfactorily explain discharge variability at Site AK2 and AK4 (large $R^{2}$, Table 4), but less well at Site AK3 (small $R^{2}$, Table 4). These rating curves were parameterized using in situ discharge measurements from Sites AK2, AK3, and AK4 spanning between $52 \%$ and $97 \%$ of observed above-zero $L_{\mathrm{w}}-d_{0}$ (Table 4, Fig. 4). Most of $L_{\mathrm{w}}-d_{0}$ outside the range covered by in situ discharge measurements at Site AK2 and AK3 occur during low flow conditions (Fig. 4). Thus, if low-flow $Q$ data are realized and sampled in future years at Site AK2 and $\mathrm{AK} 3$, these rating curves may become slightly different. Residuals between observed and estimated discharge lack structured bias at Site AK3 and AK4 suggesting that rating curve relationships are robust, and useful despite channel deepening trends at Site 3. In contrast, Site AK2 residuals are positive in 2010 deployment and negative in 2011 deployment (Fig. 4). Because Site AK2 channel bed topography is 
Table 3. Parameters describing channel depth variability and change. In the table $d_{\mathrm{c}}$ is datum to stream bed distance, $d_{\mathrm{c}}^{*}$ is mean datum to stream bed distance in 2011 .

\begin{tabular}{|c|c|c|c|c|}
\hline Parameter & Symbol & AK2 & AK3 & AK4 \\
\hline $\begin{array}{l}\text { Mean cross section standard deviation of } \\
d_{\mathrm{c}}-\bar{d}_{\mathrm{c}}^{*}(\mathrm{~m})\end{array}$ & $\bar{\sigma}\left(d_{\mathrm{c}}-\bar{d}_{\mathrm{c}}^{*}\right)$ & 0.45 & 0.17 & 0.15 \\
\hline $\begin{array}{l}\text { Mean cross section coefficient of variation } \\
\text { (standard deviation of dc } d_{\mathrm{c}}-\bar{d}_{\mathrm{c}} \text { divided } \\
\text { by mean } d_{\mathrm{w}} \text { ) }\end{array}$ & $\bar{C}_{\mathrm{v}}\left(d_{\mathrm{c}}-\bar{d}_{\mathrm{c}}^{*}, d_{\mathrm{w}}\right)$ & 0.09 & 0.65 & 0.18 \\
\hline Mean cross section water depth (m) & $\bar{d}_{\mathrm{w}}$ & 4.76 & 0.26 & 0.92 \\
\hline $\begin{array}{l}\text { Fraction of cross section with significant } \\
d_{\mathrm{c}} \text { trends (t-test, } \alpha=0.1 \text { ) }\end{array}$ & - & 0.05 & 0.84 & 0.25 \\
\hline Mean significant trends $\left(\mathrm{cm} \mathrm{yr}^{-1}\right)$ & - & 0.32 & 0.08 & 0.10 \\
\hline $\begin{array}{l}\text { Fraction of cross section with different de- } \\
\text { ployment mean } d_{\mathrm{c}} \text { (ANOVA, } \alpha=0.1 \text { ) }\end{array}$ & - & 0.82 & 0.77 & 0.39 \\
\hline $\begin{array}{l}\text { Ratio of within- and between-group vari- } \\
\text { ance determined with ANOVA }\end{array}$ & $\sigma_{\mathrm{W}}^{2} / \sigma_{\mathrm{B}}^{2}$ & 0.17 & 0.11 & 0.28 \\
\hline
\end{tabular}
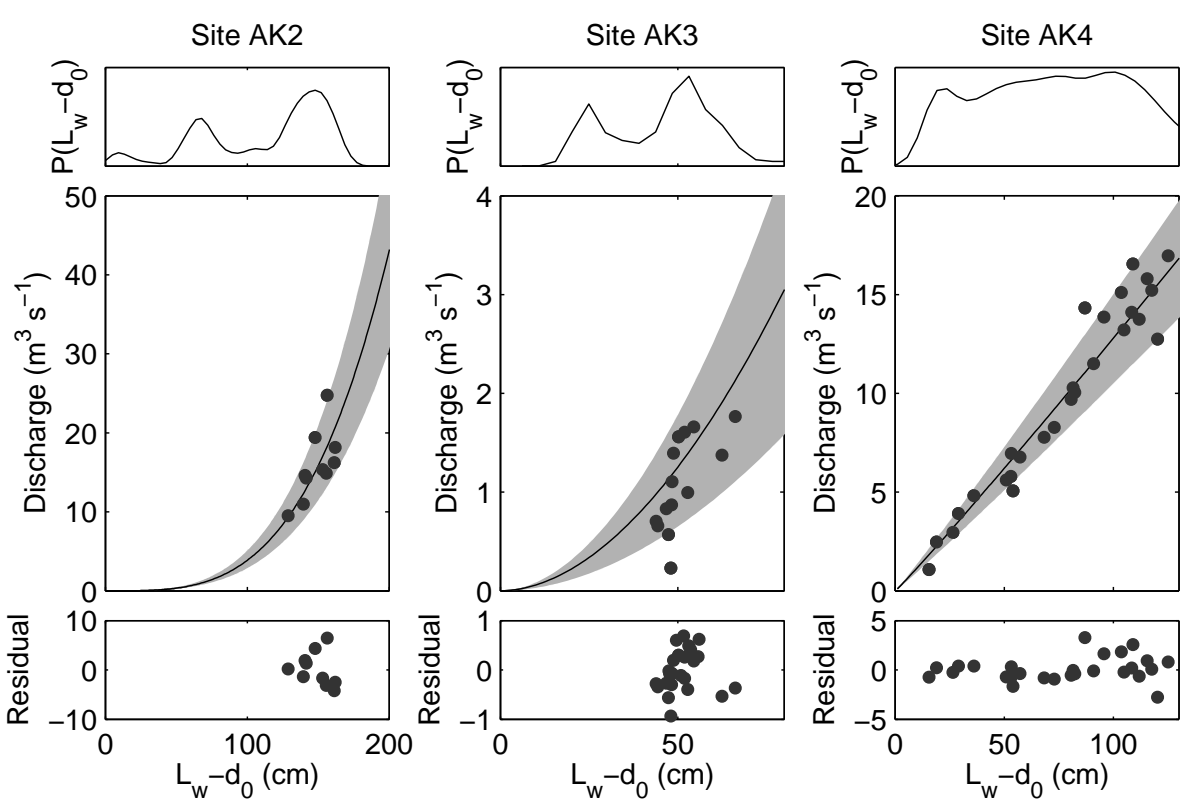

Figure 4. Probability distribution of non-zero $L_{\mathrm{w}}-d_{0}$ determined with kernel density functions (top panels), and discharge rating curves (solid black line), including observations (black points), and confidence interval (grey shaded) determined from upper and lower discharge rating curves (middle panels), and residuals between observed and estimated discharge (bottom panels). The extreme discharge estimate at maximum $L_{\mathrm{w}}-d_{0}$ observed at Site AK2 on 31 August 2008 is not shown. Minimum and maximum stage $\left(L_{\mathrm{w}}-d_{0}\right)$ associated with in situ discharge observations contain between 50 and $99 \%$ of observed above-zero stage, and observational points are largely enveloped by confidence intervals; rating curves and derived discharge uncertainties and can therefore be considered adequately representative of true conditions at these sites.

stable with no trends, AK2 residual are more likely due to $d_{\mathrm{w}}$ uncertainties, and a switch from 0.6 to $0.2 / 0.8$ velocity area method from 2010 to 2011 .

The largest source of uncertainty for estimated discharge derives from $d_{\mathrm{w}}$ measurements $\left(E_{\mathrm{d}}\right)$, followed by current me- ter instrument errors $\left(E_{\mathrm{i}}\right)$, rating curve fit $\left(E_{\mathrm{fit}}\right)$, and velocity pulsation errors $\left(E_{\mathrm{t}}\right)$ (Fig. 5). Errors are particularly large at Site $\mathrm{AK} 3$, which propagate to $Q_{\mathrm{u}}$ and $Q_{1}$ time series so that average uncertainty is $43 \%$ of $Q$, which may explain the poor rating curve fit of this site. At Sites AK2 and AK4, $Q$ 
Table 4. Model parameters and diagnostics for discharge rating curves. Rating curves are parameterized as first degree power functions: $Q=C\left(L_{w}-d_{0}\right)^{\beta}$, where $Q$ is discharge, $C$ is a multiplier, $L_{\mathrm{w}}$ is stage at levelogger installation, $d_{0}$ is estimated water depth at zero discharge, and $\beta$ is the exponent, $N$ is the number of $Q$ observations used for fitting, $f_{L_{\mathrm{w}}}$ is fraction of $L_{\mathrm{w}}$ observation gaps between 5 June 2008 and 23 July 2011.

\begin{tabular}{lllll}
\hline Parameter & Symbol & Site AK2 & Site AK3 & Site AK4 \\
\hline Rating curve multiplier & $C$ & $4.29 \times 10^{-7}$ & $7.69 \times 10^{-4}$ & $1.05 \times 10^{-1}$ \\
\hline Water depth at zero discharge $(\mathrm{cm})$ & $d_{0}$ & 101 & 0 & 0 \\
\hline Rating curve exponent & $\beta$ & 3.48 & 1.89 & 1.04 \\
\hline Number of observations used for fitting & $N$ & 11 & 25 & 29 \\
\hline $\begin{array}{l}\text { Fractional } L_{\mathrm{w}} \text { data range for observa- } \\
\text { tions used for fitting }\end{array}$ & - & 0.52 & 0.55 & 0.97 \\
\hline Coefficient of determination & $R^{2}$ & 1.00 & 0.32 & 0.94 \\
\hline $\begin{array}{l}\text { Fraction of data gaps in Q time series } \\
\text { between 5 June 2008 and 23 July 2011 }\end{array}$ & $f_{L_{\mathrm{w}}}$ & 0.58 & 0.02 & 0.22 \\
\hline
\end{tabular}

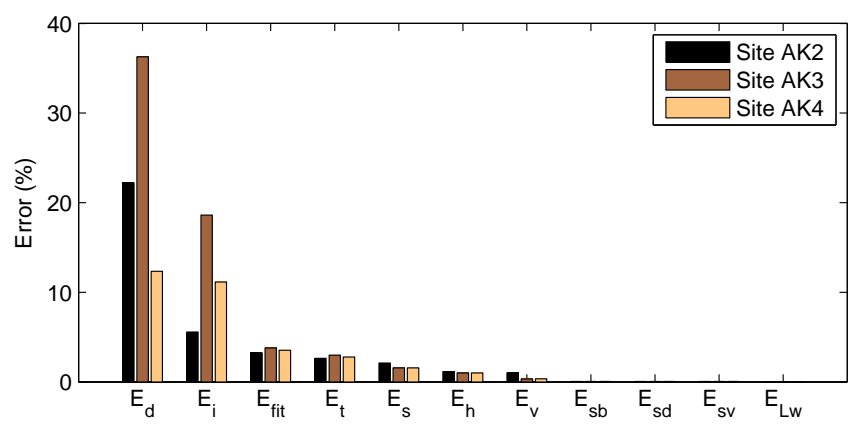

Figure 5. Components of total discharge error $(\%)$, including: $E_{\mathrm{d}}=$ depth observation error, $E_{\mathrm{i}}=$ current meter instrument error, $E_{\text {fit }}=$ rating curve error, $E_{\mathrm{t}}=$ velocity pulsation error, $E_{\mathrm{s}}=$ velocity distribution error in the vertical, $E_{\mathrm{h}}=$ flow angel error, $E_{\mathrm{v}}=$ horizontal distribution error of velocity and depth, $E_{\mathrm{sb}}=$ systematic error in width measurements, $E_{\mathrm{sd}}=$ systematic error in depth measurement, $E_{\mathrm{sv}}=$ systematic error in velocity measurements, $E_{L_{\mathrm{W}}}=L_{\mathrm{w}}$ uncertainty due to Solinst instrument precision and retrieval. The largest errors are observed at Site AK3, but all three sites have prominent errors associated with depth observation and current meter instrument.

is better constrained with mean uncertainties $30 \%$ and $19 \%$ of $Q$. In other words, true discharge is on average within $\pm 0.3 Q, \pm 0.43 Q$, and $\pm 0.19 Q$ at Sites AK2, AK3, and AK4 approximately $68 \%$ of the time.

Stream discharge at all sites displays strong seasonal, and interannual variability (Figs. 6, 7 and 8). Daily stream temperature variability is generally low, except during very low flow at Site AK4 when the sensor was exposed between 18 to 23 October in 2008, between 12 to 22 September 2009, and between 9 to 13 September 2010 (verified by comparing Levelogger temperatures with air temperatures). Some
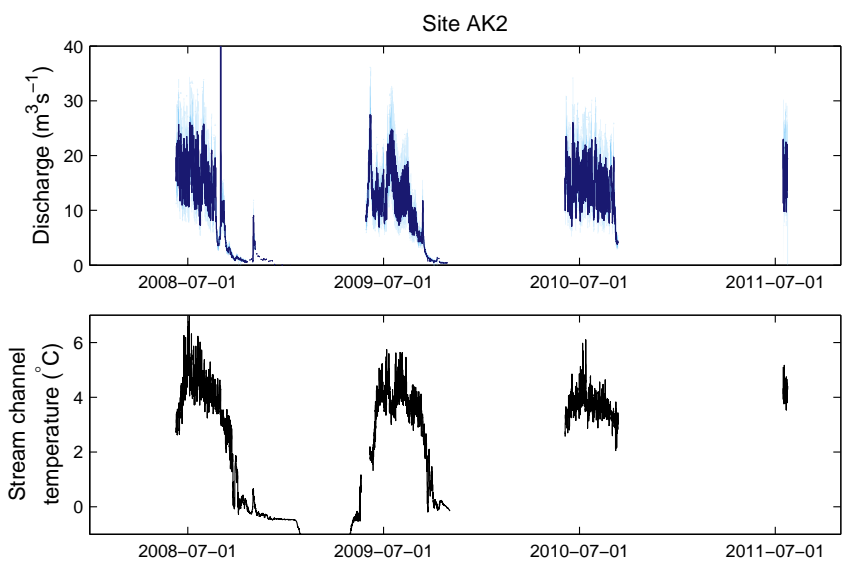

Figure 6. Site AK2 time series of retrieved discharge and measured stream temperature every $30 \mathrm{~min}$ (blue and black lines). Upper and lower ranges of discharge retrievals are shown in light blue. Vertical axes are restricted to show interannual variability; hence, the discharge outlier peak on 31 August 2008 is not shown $\left(Q_{\text {peak }}=416 \mathrm{~m}^{3} \mathrm{~s}^{-1}\right)$. Majority of wintertime discharge was not calculated at Site AK2 due to unrealistic Levelogger recordings at subzero temperatures at this site. Majority of wintertime stream temperatures were also removed as they were controlled by interannual variability in river ice thickness rather than water temperatures.

winter data retrievals were discarded, owing to implausible pressure variations, at sub zero temperatures, attributed to river ice processes (Fig. 6). Winter discharge retrievals for Site AK3 and AK4 include minor perturbations, and large discharge anomalies near the end of the year in 2008, 2009 and 2010 (only 2008 for Site AK4). Extreme discharge was recorded on 31 August 2008 at Site AK2 and AK3 coinciding with catastrophic drainage of the upstream ice dammed lake. Extreme discharges were also recorded on 6 and 7 September 
Table 5. Discharge diagnostics for study sites, and AK river sites reported in literature. $A$ is area, $Q_{\mathrm{S}}$ is approximate average summer discharge, $Q_{\mathrm{s}} / A$ is specific discharge in $10^{-8} \mathrm{~m} \mathrm{~s}^{-1}$.

\begin{tabular}{lllll}
\hline Site & $A\left(\mathrm{~km}^{2}\right)$ & $Q_{\mathrm{s}}\left(\mathrm{m}^{3} \mathrm{~s}^{-1}\right)$ & $Q_{\mathrm{s}} / A\left(10^{-8} \mathrm{~m} \mathrm{~s}^{-1}\right)$ & Reference \\
\hline AK3 & 7.8 & $1^{1}$ & 13 & This study \\
AK4 & 64.2 & $12^{1}$ & 18 & This study \\
AK2 & 101.4 & $15^{1}$ & 15 & This study \\
Russell glacier & $364-670$ & $50^{2}$ & $7.5-14$ & Van de Wal and Russell (1994) \\
Watson River & 6279 & $200-300^{3}$ & $3.2-4.8$ & Mernild and Hasholt (2009) \\
\hline
\end{tabular}

${ }^{1}$ Median discharge between 15 July and 15 August in 2008-2011,

${ }^{2}$ Approximate average derived from Fig. 9 in van de Wal and Russel (1994),

${ }^{3}$ Approximate summer averages derived from Fig. 2 in Mernild and Hasholt (2009).
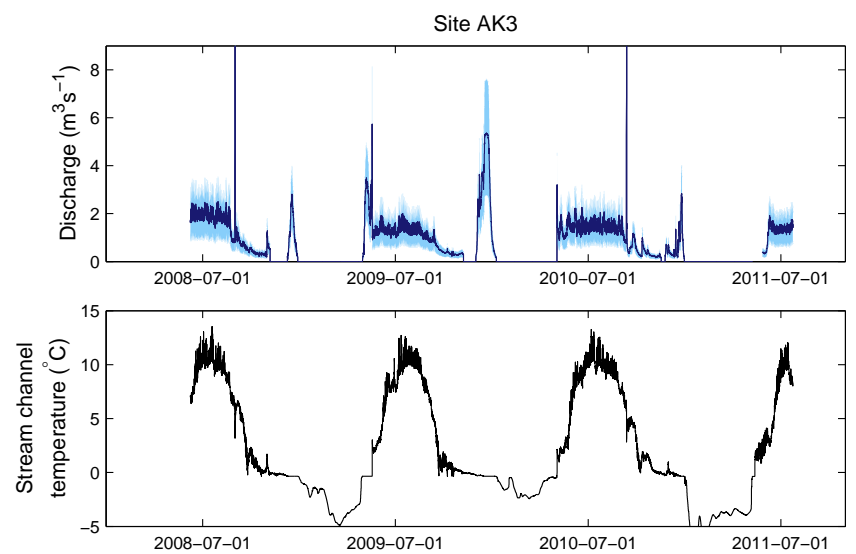

Figure 7. Site AK3 time series, same as in Fig. 6. Vertical axes are restricted to show interannual variability; hence, discharge outlier peaks on 31 August 2008 and 9 September 2010 is not shown $\left(Q_{\text {peak }}=31 \mathrm{~m}^{3} \mathrm{~s}^{-1}\right.$, and $Q_{\text {peak }}=85 \mathrm{~m}^{3} \mathrm{~s}^{-1}$, respectively). Subzero stream temperatures indicate frozen conditions and zero stream flow, except during prolonged periods with unchanged temperatures indicative of phase change and flowing water.

2010 at Site AK4, and on 11 September at Site AK3 (Site AK2 records data gap begin 11 September 2010). Site AK3 discharge anomalies may be a result of backflow, as this stream branch is upstream of the input of the ice dammed lake into the AK river system but yet in proximity to the lake where the ice dammed lake discharges into (Lake B, Fig. 1).

Summer discharge at five AK-river sites are proportional to ice sheet drainage area, and specific discharge inversely proportional to area with the exception of Site AK3 (Table 5). At Site AK3, specific discharge is less than at the next larger site (Site AK4). This may be due to larger discharge uncertainty at Site AK3, but also due to real differences in runoff production intensity as these watersheds do not overlap spatially.
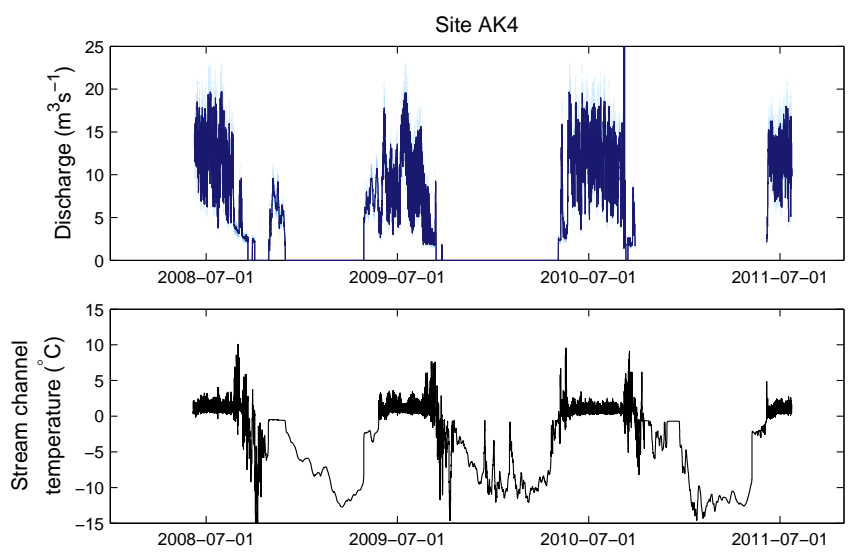

Figure 8. Site AK4 time series, same as in Fig. 7. Vertical axes are restricted to show interannual variability; hence, the discharge outlier peak between 6 to 7 September 2010 is not shown $\left(Q_{\text {peak }}=56 \mathrm{~m}^{3} \mathrm{~s}^{-1}\right)$. Similar to Site AK3, subzero stream temperatures indicate frozen conditions and zero stream flow, except during prolonged periods with unchanged temperatures indicative of phase change and flowing water. Additionally, sensor air exposure between 18 to 22 October 2008, 12 to 23 September 2009, and 9 to 13 September 2010 resulted in subzero and highly variable stream temperatures.

\section{Discussion}

Discharge uncertainties for the three study sites are considerable, but discharge magnitudes are internally consistent within the AK-river basin. The average $\sim 68 \%$ confidence interval varies between $\pm 19 \%$ and $\pm 46 \%$ of $Q$ estimates. These error magnitudes are much larger than previously assumed in this river system, e.g. $10 \%$ (van de Wal and Russell, 1994). The largest error source is channel depth observations. At Sites AK2 and AK4, channel depth errors are probably dominated by measurement uncertainties, because stream channels were stable, and unchanging, owing to structural reinforcement and bedrock incision. In contrast, Site AK3 channel cross section profile changed, suggesting that dynamic changes in channel morphology at Site AK3 
added to depth observation uncertainty here. However, Site AK3 also has the lowest discharge, which is disproportionally influenced by depth measurement errors. Thus, it is possible that measurement uncertainties dominate at Site AK3 as well.

While majority of discharge at subzero stream temperatures have been discarded for Site AK2, sub zero temperatures at Site AK3 and AK4 suggest that these streams are mostly frozen during winter. Exceptions are 1-3 large $L_{\mathrm{w}}$ anomalies sustained for several days at Sites AK3 and AK4 which suggest the possibility of occasional water discharge events at these sites even during winter. However, further investigation is needed to confirm this possibility. Regardless, estimated winter discharge magnitudes should be considered particularly uncertain given that specialized techniques are needed to determine discharge during winter ice conditions (Pelletier, 1990; WMO, 2010a, b). These techniques are not applied here because they require in situ discharge measurements to be collected in winter, whereas all field deployments were in summer.

Although all three monitored sites along the Akuliarusiarsuup Kuua River's northern tributary have near-ideal geomorphological properties, and similar data collection methodologies, uncertainty ranges identified in this study cannot be transferred to downstream sites or to other riverine observational sites in Greenland. This is due to strong site dependency as illustrated by large uncertainty variation between Sites AK2, AK3 and AK4. Regardless, this study highlights large uncertainties in this river system, primarily introduced by channel depth observations. This study also shows how discharge errors can be determined and used to constrain confidence intervals of $Q$ time series. Given the large errors encountered in this study, comprehensive uncertainty analysis should be considered more widely in similar data collections efforts.

\section{Conclusions}

Here, half-hourly hydrologic datasets of stage, temperature, and derived discharge are presented for previously unmonitored sites in proglacial streams and lakes draining the Greenland ice sheet near Kangerlussuaq. The dataset adds to a small collection of hydrologic datasets for Greenland, which are particularly rare for streams and rivers draining the ice sheet near its edge. Encountered limitations associated with turbulent water flow, high sediment bedloads, instruments, and observations are mitigated through quantitative error assessment. Previous studies present discharge estimated from stage observations at three sites situated $3 \mathrm{~km}$, $9 \mathrm{~km}$, and $32 \mathrm{~km}$ downstream of Site AK2 (Mernild and Hasholt, 2009; Russell et al., 1995; Russell, 2007; van de Wal and Russell, 1994), but do not include uncertainty ranges. Thus, this study is the first to apply a statistical data uncertainty analysis to discharge measurements in the Akuliarusiarsuup Kuua river system.

The resulting stage, discharge, and temperature dataset is useful for understanding riverine conditions in the Southwest Greenland proglacial environment, the response of Greenland ice sheet meltwater production to climatic variables, and possibly hydrologic processes operating within the ice sheet itself. Ongoing data collections at these sites are planned until at least 2013 so that the utility of these time series may be extended further.

Data are available in Open Access at: doi:10.1594/PANGAEA.762818.

Acknowledgements. This research was funded by the NASA Cryosphere Program managed by Thomas Wagner, grants NNG05GN89G and NNX11AQ38G.

Edited by: H. Grobe

\section{References}

Ashmore, P. and Sauks, E.: Prediction of discharge from water surface width in a braided river with implications for at-astation hydraulic geometry, Water Resour. Res., 42, W03406, doi:10.1029/2005WR003993, 2006.

Baker, D., Escher-Vetter, H., Moser, H., Oerter, H., and Reinwarth, O.: A glacier discharge model based on results from field studies of energy balance, water storage and flow, in: Hydrological Aspects of Alpine and High Mountain Areas (Proceedings of the Exeter Symposium, July 1982), 103-112, 1982.

Bartholomew, I., Nienow, P., Sole, A., Mair, D., Cowton, T., Palmer, S., and Wadham, J.: Supraglacial forcing of subglacial drainage in the ablation zone of the Greenland ice sheet, Geophys. Res. Lett., 38, L08502, doi:10.1029/2011GL047063, 2011.

Box, J., Yang, L., Bromwich, D., and Bai, L.: Greenland Ice Sheet Surface Air Temperature Variability: 1840-2007, J. Climate, 22, 4029-4049, doi:10.1175/2009JCLI2816.1, 2009.

Box, J. E., Cappelen, J., Decker, D., Fettweis, X., Mote, T. L., Tedesco, M., and van de Wal, R.: 2010 Greenland, in: Arctic Report Card 2010, available at: www.arctic.noaa.gov/reportcard, 2010.

Cuffey, K. and Paterson, W. S. B.: The Physics of Glaciers, 4th Edn., Elsevier Inc., 2010.

Dethloff, K., Dorn, W., Rinke, A., Fraedrich, K., Junge, M., Roeckner, E., Gayler, V., Cubasch, U., and Christensen, J. H.: The impact of Greenland's deglaciation on the Arctic circulation, Geophys. Res. Lett., 31, L19201, doi:10.1029/2004GL020714, 2004

Driesschaert, E., Fichefet, T., Goosse, H., Huybrechts, P., Janssens, I., Mouchet, A., Munhoven, G., Brovkin, V., and Weber, S. L.: Modeling the influence of Greenland ice sheet melting on the Atlantic meridional overturning circulation during the next millennia, Geophys. Res. Lett., 34, L10707, doi:10.1029/2007GL029516, 2007.

Elliston, G. R.: Water movement through the Gornergletscher, Int. Assoc. Sci. Hydrol., 95, 79-84, 1973.

Fichefet, T., Poncin, C., Goosse, H., Huybrechts, P., Janssens, I., and Treut, H. L.: Implications of changes in freshwater flux from the Greenland ice sheet for the climate of the 21st century, Geophys. Res. Lett., 30, 1911, doi:10.1029/2003GL017826, 2003. 
Fountain, A. G. and Tangborn, W.: Overview of Contemporary Techniques, in: Techniques for Prediction of Runoff from Glacierized Areas, edited by: Young, G. J., International Association of Hydrological Sciences (Red Book), 149, 27-41, 1985.

Hock, R. and Noetzli, C.: Areal melt and discharge modelling of Storglaciaren, Sweden, Ann. Glaciol., 24, 211-216, 1997.

Jungclaus, J. H., Haak, H., Esch, M., Roeckner, E., and Marotzke, J.: Will Greenland melting halt the thermohaline circulation?, Geophys. Res. Lett., 33, L17708, doi:10.1029/2006GL026815, 2006.

Klok, E. J., Jasper, K., Roelofsma, P., Gurtz, J., and Badouz, A.: Distributed hydrological modelling of a heavily glaciated Alpine river basin, Hydro. Sci.-J. Sci. Hydro., 46, 553-570, doi:10.1080/02626660109492850, 2001.

Lewis, S. and Smith, L.: Hydrologic drainage of the Greenland Ice Sheet, Hydrol. Process., 23, 2004-2011, doi:10.1002/hyp.7343, 2009.

METI and NASA: Japan's Ministry of Economy, Trade and Industry, METI, and National Aeronautics and Space Administration, NASA, available at: http://asterweb.jpl.nasa.gov/gdem.asp, last access: 8 September 2009, 2010.

Mathews, W. H.: Discharge of a glacial stream, International Association of Hydrological Sciences, 63, 290-300, 1963.

Mernild, S. H. and Hasholt, B.: Observed runoff, jokulhlaups and suspended sediment load from the Greenland ice sheet at Kangerlussuaq, West Greenland, 2007 and 2008, J. Glaciol., 55, 855858, doi:10.3189/002214309790152465, 2009.

Mernild, S. H., Hasholt, B., Kane, D. L., and Tidwell, A. C.: Jökulhlaup Observed at Greenland Ice Sheet, Eos Trans. AGU, 89, 321-322, doi:10.1029/2008EO350001, 2008.

Mernild, S. H., Liston, G. E., Steffen, K., van den Broeke, M., and Hasholt, B.: Runoff and mass-balance simulations from the Greenland Ice Sheet at Kangerlussuaq (Søndre Strømfjord) in a 30-year perspective, 1979-2008, The Cryosphere, 4, 231-242, doi:10.5194/tc-4-231-2010, 2010.

Mernild, S., Liston, G., Hiemstra, C., Christensen, J., Stendel, M., and Hasholt, B.: Surface Mass Balance and Runoff Modeling Using HIRHAM4 RCM at Kangerlussuaq (Sondre Stromfjord), West Greenland, 1950-2080, J. Climate, 24, 609-623, doi:10.1175/2010JCLI3560.1, 2011.

Nienow, P., Sharp, M., and Willis, I.: Seasonal changes in the morphology of the subglacial drainage system, Haut Glacier d'Arolla, Switzerland, Earth Surf. Proc. Land., 23, 825-843, 1998.

Pelletier, P.: A review of techniques used by Canada and other Northern countries for measurement and computation of streamflow under ice condtions, Nord. Hydrol., 21, 317-340, 1990.

Pfeffer, W., Harper, J., and O'Neel, S.: Kinematic constraints on glacier contributions to 21 st-century sea-level rise, Science, 321 , 1340-1343, doi:10.1126/science.1159099, 2008.
Rignot, E., Box, J., Burgess, E., and Hanna, E.: Mass balance of the Greenland ice sheet from 1958 to 2007, Geophys. Res. Lett., 35, L20502, doi:10.1029/2008GL035417, 2008.

Russell, A. J.: A Comparison of 2 Recent Jokulhluaps from an Icedammed Lake, Sondre Stromfjord, West Greenland, J. Glaciol., 35, 157-162, 1989.

Russell, A. J.: Controls on the sedimentology of an icecontact jökulhlaup-dominated delta, Kangerlussuaq, west Greenland, Sedimentary Geology, 193(1-4), 131-148, doi:10.1016/j.sedgeo.2006.01.007, 2007.

Russell, A. J.: Jökulhlaup (ice-dammed lake outburst flood) impact within a valley-confined sandur subject to backwater conditions, Kangerlussuaq, West Greenland, Sediment. Geol., 215, 33-49, doi:10.1016/j.sedgeo.2008.06.011, 2009.

Russell, A. J., Van Tatenhove, F. G. M., and Van De Wal, R. S. W.: Effects of ice-front collapse and flood generation on a proglacial river channel near kangerlussuaq (Søndre Strømfjord), west greenland, Hydrol. Process., 9, 213-226, doi:10.1002/hyp.3360090207, 1995.

Russell, A. J., Carrivick, J., Ingeman-Nielsen, T., Yde, J. C., and Williams, M.: A new cycle of jökulhlaups at Russell Glacier, Kangerlussuaq, West Greenland, J. Glaciol., 57, 238246, doi:10.3189/002214311796405997, 2011.

Sauer, V. and Meyer, R.: Determination of error in individual discharge measurements, USGS Open File Rep. No. 92-114, US Geological Survey, Norcross, Ga., 1992.

Smith, L., Isacks, B., Bloom, A., and Murray, A.: Estimation of discharge from three braided rivers using synthetic aperture radar satellite imagery: Potential application to ungaged basins, Water Resour. Res., 32, 2021-2034, 1996.

Solinst Inc.: Levelogger User guide Software 3.4.1, 16 January 2011.

van den Broeke, M., Bamber, J., Ettema, J., Rignot, E., Schrama, E., van de Berg, W., van Meijgaard, E., Velicogna, I., and Wouters, B.: Partitioning Recent Greenland Mass Loss, Science, 326, 984-986, doi:10.1126/science.1178176, 2009.

van de Wal, R. S. W. and Russell, A. J.: A comparison of energy balance calculations, measured ablation and meltwater runoff near Søndre Strømfjord, West Greenland, Global Planet. Change, 9, 29-38, doi:10.1016/0921-8181(94)90005-1, 1994.

Verbunt, M., Gurtz, J., Jasper, K., Lang, H., Warmerdam, P., and Zappa, M.: The hydrological role of snow and glaciers in alpine river basins and their distributed modeling, J. Hydrol., 282, 3655, doi:10.1016/S0022-1694(03)00251-8, 2003.

WMO: Manual on stream gauging - Computation of discharge, World Meteorological Organization., 2010a.

WMO: Manual on stream gauging - Field methods, World Meteorological Organization., $2010 \mathrm{~b}$. 